\title{
Financial literacy: What is the fact of the digital startups "Startup Singo Edan Malang"?
}

\author{
Hanif Rani Iswari ${ }^{1}$, Cicik Retno Wati ${ }^{2}$ \\ Universitas Widyagama, Malang ${ }^{1}$, Universitas Brawijaya' Malang $^{2}$ \\ \{rani@widyagama.ac.id¹, cicikrwati@student.ub.ac.id²\}
}

\begin{abstract}
The purpose of this research is to analyze financial literacy in the digital start-up business of "Startup Singo Edan Malang" community. The research approach used quantitative and qualitative with descriptive analysis methods. The sample of this study was 117 respondents who were obtained through questionnaires and open interviews. The results were obtained information if knowledge of credit interest rates is preferred in making credit decisions. This is evident from the experience of short-term credit in banking financial institutions. The fact that investment knowledge is obtained is if there is more understanding of banking products than capital market investment products. However, the investment experience is not in line with this investment knowledge, because of community integration. For financial management regarding credit guarantees, the level of knowledge is high, but not with shortterm and long-term financial management. Experience in short-term financial management, especially credit cards, is based on a precautionary motive.
\end{abstract}

Keywords: Financial Knowledge, Financial Experience, Startup, Financial Literacy.

\section{Introduction}

Startup companies or what are currently better known as start-up businesses in recent years. Malang City is one of the cities that has the potential for the development of start-up businesses. Based on the online news on the Techinasia (2019) page, it is explained that Malang City is one of the cities that has received the incubator and accelerator program for start-up businesses in Indonesia. This is one of the reasons why Malang City is a place that needs to be studied further regarding the behavior of start-up business owners related to business growth. The growth of the start-up business was also balanced with the growth in the value of start-up investment in Indonesia. Data collected in online news shows that the highest growth in start-up investment in 2019 came from Vietnam at $158.2 \%$, followed by Thailand at $73.1 \%$, however, the growth of start-up investment in Indonesia has decreased from $76 \%$ to $56 \%$ (https://databoks.katadata.co.id, 2019). Even though the value of start-up investment growth in Indonesia has decreased, this figure is still quite good, considering how the condition of start-up businesses in Indonesia is still at a developing stage. However, the conditions for the development of start-up businesses in Indonesia are not balanced with the level of human resources possessed by the owners and managers of start-up businesses. Data 
from MIKTI and Teknopreneur Indonesia (2018) shows that the level of human resources is one of the main problems faced in the growth of start-up businesses with a percentage of 24.41 percent.

Based on the research from Kachlami \& Yazdanfar (2016); Kozlenkova et al. (2014) said that the ability of human resources in managing capital can increase competitive advantage and increase company growth. Other research also explains that quality financial literacy is a major milestone in the growth and development of start-up businesses (Eniola \& Ektebang, 2014). Huston (2010) reviewed 71 literature which explained that there are two main things in the dimensions of financial literacy, namely understanding, and application, which in some literature sometimes call it knowledge and experience. Several subsequent studies also explained that good knowledge and experience in the financial sector will have a positive impact on financial behavior (Ameliawati \& Setiyani, 2018; Tang \& Baker, 2016; Yong et al., 2018).

This research was conducted with the aim of research aiming at analyzing financial literacy in the digital start-up business of the Singo Edan Malang startup community. Financial knowledge and financial experience play an important role in supporting decision making, both short-term decisions and long-term decisions related to finance to achieve company goals. This is because financial knowledge and financial experience are related to the ability of the start-up business owner or manager to make effective decisions. Previous research results suggest that the absence of financially experienced boards appears to be correlated with the failures of many financial institutions (Fernandes \& Fich, 2011). According to Nonaka (2002: 445) explains that experience is classified as tacit knowledge obtained from the action, commitment, and involvement in a certain context. The study from Tuffour et al. (2020) supports the previous statement which explains the role of financial knowledge and financial experience, that the low level of financial knowledge of a person experiences difficulties and lack of skills in managing company finances. Besides, the low level of financial knowledge is also a factor in the lack of motivation to be actively involved in personal and corporate financial planning (Loke, 2015). Thus, the low level of financial knowledge and financial experience will be an obstacle to the growth of start-up businesses in Indonesia, especially in Malang.

\section{Literature Review}

\subsection{Financial Knowledge}

Financial knowledge is one component of financial literacy if it is related to the financial sector. According to research Huston (2010) says that financial literacy has two dimensions, namely "understanding" and "use", where the dimension of "understanding" refers to the knowledge possessed by each individual. Supporting the previous statement, Hasting et al. (2012) also stated that financial literacy has various meanings which refer to various knowledge such as knowledge related to financial products, financial concepts, having math or numeracy skills, to support effective financial decision making. However, financial literacy is different from financial knowledge. The context of financial literacy is broader when compared to financial knowledge, where financial literacy does not only include individual knowledge but also includes elements of behavior or attitudes of individuals in financial management. Huston (2010) explains that financial knowledge is an integral dimension, and is not equivalent to financial literacy, because financial literacy is a component of human capital 
used in financial activities, to increase lifetime utility from consumption, namely, behavior that increases financial well-being.

Financial knowledge has an important role in life both to support short-term and long-term needs related to financial decision making. This is because financial knowledge can be obtained from information about finances that are systematically arranged and understood further. With the information that is arranged systematically, individuals can make financial decisions and manage finances effectively. However, the level of financial knowledge of each individual is different, depending on the individual's ability to absorb existing information or knowledge. A person who has a low level of financial knowledge will experience difficulties and lack of skills in managing company finances (Tuffour et al., 2020), and this is one of the factors that lack the motivation to be actively involved in personal and corporate financial planning (Loke, 2015). Conversely, someone who has a high level of financial knowledge will have a sense of self-confidence related to financial knowledge, financial products, financial concepts, and decision making related to finance. Lim et al. (2018) said that the level of financial knowledge possessed by individuals or company managers will affect individuals in the decision-making process. Thus, financial knowledge is an important aspect for any entrepreneur or financial manager to have.

\subsection{Financial Experience}

Financial Experience is formed because of a person's behavior related to financial management that is carried out repeatedly, thus indirectly forming experience for individuals in this field. Ameliawati \& Setiyani (2018) said that financial experience is a person's learning behavior in managing personal finances so that someone who has adequate financial experience can behave more wisely in managing their finances than others. Financial experience as a factor related to financial management behavior is an event that occurs in individuals in response to several types of stimuli (Ameliawati \& Setiyani, 2018). In other words, financial behavior is an antecedent that can shape an experience.

Several previous studies have also stated that an individual's ability comes from experience (Fernandes \& Fich, 2011; Jiang et al., 2013), where experience is the main source of learning (Frijns et al., 2014). The study also explains that CEOs or financial managers who have experience have more potential in developing their business than CEOs who are less experienced. Fernandes \& Fich (2011) say that the absence of financially experienced boards appears to be correlated with the failures of many financial institutions. This is because the experience possessed by a business owner or manager will influence the decisions taken. Not only that, business owners or managers who have more experience will feel more familiar or more familiar with the conditions of a dynamic company environment so that the business owner or manager can respond responsively to existing problems. Supporting the previous statement, the research results of Jiang et al. (2013) also explained that CEOs with financial experience provide more precise income information and higher quality financial reports. Thus, financial experience has an important role in supporting company growth.

\section{Reseach Method}

This study uses quantitative and qualitative research approaches, with two variables, namely financial knowledge and financial experience variables. The population and sample in this study are a digital start-up business in Malang City, with the sampling technique used is 
simple random sampling. The types of data used in this research are primary data and secondary data. Primary data were obtained in two ways, namely distributing questionnaires and openly interviewing start-up businesses in Malang City. There are three sources used in this research, namely the head of the start-up business community and two people who own the start-up business. Secondary data of this research comes from literature and documents related to research variables. The Linkert scale was used in the distribution of the questionnaire for this study with a scale of 1 (strongly disagree) until 5 (strongly agree). The questionnaires collected in this study and declared valid were 117 respondents.

The indicators used in this research variable were adapted from previous research and adapted to the needs of the study. Financial knowledge variables are measured by 15 questionnaire statement items adapted from Atkinson \& Messy (2012); Clark et al. (2009); Du et al. (2011); Hantrakul et al. (2012). The financial experience variable is measured by 23 questionnaire statement items referring to the research of Lusardi \& Tufano (2015); Ying et al. (2015); Yong et al. (2018). Analysis of the data used for the results of the questionnaire distribution used descriptive analysis assisted by smart PLS software, while data analysis used for data originating from interviews used source triangulation.

\section{Result and Discussion}

\subsection{Respondents Distribussion}

Tabel 1. Respondents Distribussion

\begin{tabular}{lcc}
\hline \multicolumn{1}{c}{ Information } & Procentage & Frekuency \\
\hline Gender & & \\
- Female & 65.81 & 77 \\
- Male & 34.19 & 40 \\
\hline Age & & \\
- 18 s/d 27 years & 63.25 & 74 \\
- >27 s/d 37 years & 23.93 & 28 \\
- >37 s/d 47 years & 8.55 & 10 \\
- >47 s/d 57 years & 4.27 & 5 \\
- > 57 years & 0 & 0 \\
\hline Education & & \\
- SMP & 0.85 & 1 \\
- SMA & 30.77 & 36 \\
- Undergraduate/Diploma & 64.96 & 76 \\
- Master Degree & 3.42 & 4 \\
\hline Operating Income Per Month & & \\
- Less than Rp 3.500.000 & 52.14 & 61 \\
- >Rp 3.500.000,- s/d Rp 5.000.000,- & 23.93 & 28 \\
- >Rp 5.000.000,- s/d Rp 10.000.000,- & 11.97 & 14 \\
- >Rp 10.000.000,- & 11.97 & 14 \\
\hline Operating Income Per Year & & \\
- Less than Rp 42.000.000,- & 64.10 & 75 \\
- >Rp 42.000.000,- s/d Rp 60.000.000,- & 14.53 & 17 \\
- >Rp 60.000.000,- s/d Rp 120.000.000,- & 9.40 & 11 \\
- >Rp 120.000.000,- & 11.97 & 14 \\
\hline
\end{tabular}




\begin{tabular}{lcc}
\hline \multicolumn{1}{c}{ Information } & Procentage & Frekuency \\
\hline Long Business Standing & & \\
- $<6$ months & 29.06 & 34 \\
- 6 months - 12 months & 23.08 & 27 \\
- 12 months - 24 months & 18.80 & 22 \\
- 24 months - 36 months & 29.06 & 34 \\
\hline
\end{tabular}

\subsection{Financial Knowledge}

The results of the descriptive analysis show that the average for item X1.1 with the item statement "If I delay or are late in making debt bill payments, then submitting additional debt is made easier" of 2.632479 . From the average item X1.1, the percentage of respondents who were above the average was $54.70 \%$ or as many as 64 respondents. The data shows that as many as 64 respondents answered the statement item X1.1 on a scale of 3 (normal) to 5 (strongly agree). This shows that the majority of respondents do not know that the late payment of debt will affect the level of trust in banks in providing additional credit. If someone is late in paying a debt, then the bank will doubt whether the business owner can pay the credit given or not in the future, if the amount of credit is added. Besides, most of the business owners, from respondents on a scale of 3 to 5 , mostly have their business length of time between $>6$ months to 12 months, so business owners in this category are hesitant to apply for a loan or not. The result of this analysis is supported by the results of an interview which explains that: "My business has only been established for about a year. The flow of bank loans is also complicated. so, I don't need a loan first, maybe later." (informant 1, 2020)

On the other hand, $45.30 \%$ or 53 respondents chose an answer scale of 1 (strongly disagree) and 2 (disagree), or below the average. This shows that business actors understand or know the mechanism of bank credit and how it impacts subsequent credit applications. This situation is supported by the level of education of the business owner. More than half of the respondents who chose the answer scale of 1 or 2, have a Bachelor / Diploma level, although some of them have a high school education, the business has been around 12 months to 36 months long, so business owners are experienced in long-term loans in short. This is consistent with the statement of one business owner who said that: "I know about bank credit because I used to work at a bank for 4 years, miss. 2 years I worked in the search for customers, then moved to an account executive, miss. Part of the SME credit application survey, miss". (informant 2, 2020)

In contrast to item X1.1, the average of item X1.2 with the question item "I can save quite a lot of money for debt interest payments, if I choose a debt with a maturity of 15 years rather than 30 years (credit interest rate)" is 3.495726. From an average of $3.495726,53.85 \%$ or 63 respondents answered the questionnaire with an answer scale of 4 (agree) to 5 (strongly agree). This shows that the 63 respondents know loan interest rates. As previously explained, the level of education and work experience affect the level of knowledge of the research respondents. Knowledge of business owners regarding business loan interest rates will help business owners in making business financing decisions. Besides, work experience and experience from applying for loans also affect business owners in making business financing decisions. "Yes, although I was not taught about credit in college, I often participate in entrepreneurial training such as on the skill academy website, prakerja.go.id, which also explains financial matters. I also have experience borrowing money from the bank for my other business, so I understand." (Informant 3, 2020) 
The percentage of respondents answers who are below the average is $46.15 \%$ or as many as 54 respondents. This shows that business owners lack knowledge of loan interest rates. This condition occurs because most business owners have an annual gross income of less than Rp. $42,000,000$, or the length of time their business has been established is between less than 6 months to 1 year. Thus, business owners are hesitant to carry out bank loans. After further investigation, the characteristics of respondents who did not know about loan interest rates were mostly the same respondents as respondents in item X1.1 who chose an answer scale of 3 (normal) to 5 (strongly agree). "Besides my business, it is still around one year, the gross income per year of my business is still small, sufficient for operational costs and capital turnover. If I apply for a loan from the bank, I'm afraid I won't be able to pay the interest, miss." (Informant 4, 2020)

The average of item X1.3 with the statement item "Creditors should tell me, what is the annual interest rate I must pay on loans offered by these creditors" is 4.410256. The distribution of respondent data is above the average of 4.410256 on item X1.3, with the percentage of answers of $61.56 \%$ or as many as 72 respondents. This percentage shows that 72 respondents have an answer scale of 4 (agree) to 5 (strongly agree). This shows that information on annual credit interest rates is very important for business owners to know, especially business owners who are already familiar with bank credit. Business owners who are familiar with banking credit indirectly understand that interest rate information is very important for making short-term financial plans or business strategies. Although not all business owners can carry out the short-term financial management, interest rate information is very important for business owners to estimate whether their business can afford to pay the loan principal and interest rates. "Important miss. It's like buying a cellphone online, let's say buying in the marketplace, you have to know the specifications of the cellphone, how much is the postage, what warranty and how long, what is the shop review, right? So the same, me too, I have to know what the interest rate on loans is per year. Even though my business financial management is still simple, at least I can estimate the high-interest rate or not, my business is strong to pay the principal of the loan with the same interest or not." (Informant 5, 2020)

The data distribution of respondents who are below the average of 4.410256 on item X1.3, with the percentage of answers of $38.54 \%$ or as many as 45 respondents. This shows that business owners do not need information on loan interest rates. This condition does not necessarily indicate that the business owner does not know the impact of whether the loan interest rate will affect the business or not, but there is a possibility that information on the amount of the credit rate is not a top priority for the business owner. This condition is because the source of business financing does not come from debt, so information on loan interest rates is not so important for business owners. "I know miss, a large credit interest rate or not is important, but my business has not made a loan, or I have no debt. So for the time being, the credit interest rate information is not very useful or important for my business."(Informant 6 , 2020)

Average with the statement item "If I refinance (refinancing) mortgage debt (for example: taking debt for home purchases) repeatedly from time to time, then I pay additional provision fees (additional costs if I take new debt) in each process. renewal of my debt "amounting to 3.230769 . The percentage of the data distribution of respondents who are above the average is $45.30 \%$ or as many as 53 respondents. This percentage shows that 53 respondents have an answer scale of 4 (agree) to 5 (strongly agree). This shows that the business owner knows about the long-term debt mechanism. Most of the respondents on this statement item have the same condition as the respondent's item X1.2, where the respondent's education and experience support their knowledge of the long-term debt mechanism. In addition, the 
statistical results of this item show that most business owners at the bachelor / diploma level with a gross business income of less than IDR 42,000,000 to IDR 60,000,000 are interested in long-term financing or long-term debt. Not only that, some business owners with a gross income level of between Rp. 60,000,000 to more than Rp. 120,000,000 per year are also interested in long-term financing. This is also evidenced from interviews with business owners who explain: "Yes miss, I have attended one of the pieces of training on long-term and shortterm business financing, one of which is a mortgage. Because of the training, I know and am interested in finding more information." (Informant 7, 2020)

The percentage of the data distribution of respondents below the average X1.3 is $54.70 \%$ or as many as 64 respondents. This condition shows that the business owner does not know about the long-term financing mechanism, but several conditions also make the business owner give an answer scale of 1 (strongly disagrees) to 3 (normal). This condition is like a business owner knowing long-term financing but has never tried to do this financing. So that business owners sometimes feel doubt whether they understand the long-term financing mechanism. This is as explained by one source from the game developer business owner: "I understand in theory, but if asked in detail, I doubt it. Honestly, my business has never applied for long-term financing." (Informant 8, 2020)

The average statement item X1.5 is 4.188034 , with the percentage of respondent data above the average of $50.43 \%$ or as many as 59 respondents. This shows that 59 respondents chose an answer scale of 4 (agree) to 5 (strongly agree). This condition explains that the respondent knows that the annual credit interest rate for comparison of credit offers is very important. While the percentage distribution of respondents is below the average of $49.57 \%$ or as many as 58 respondents. Although the percentage in the statement item X1.5 is almost equal, this condition is following the statement item X1.3. Most business owners feel that the information on the amount of loan interest rates offered is very important, this is because business owners can choose the most optimal rate for the company and according to the needs of the company from several existing offerings. But on the other hand, some business owners feel that they do not need it because the source of their business financing does not come from debt, so business owners do not feel the need to compare these credit offers.

The dimensions of savings products and capital market investment products indicate that understanding of banking products is better than the understanding of capital market investment products. This is shown in statement item X1.1, namely "I prefer to invest my money to buy bonds when the bank interest rate drops to lower than the bond coupon" which explains as many as 48 respondents or $41.03 \%$ of respondents chose an answer scale of 4 (agree) to 5 (totally agree). Besides, statement item X1.7 also explains that business owners have a better understanding of banking products. The percentage of statement items X1.7 shows that $41.03 \%$ or as many as 48 respondents choose an answer scale of 4 (agree) to 5 (strongly agree). The understanding of banking products is better because business owners are more familiar with banking products, where business owners often deal with banking products than capital market products. These results are also supported by the results of interviews which explain: "So far, I don't really understand about investment. All I know is the products offered by banks. Sometimes when I open an account for my business, I am offered various banking products. " (Informant 10, 2020)

The condition business owners who are not too familiar with capital market investment products tend to have a low understanding of capital market investment products. This is indicated by the percentage of respondents on the statement item X1.9 and item X1.10. The percentage of respondents to the statement item X1.9 was $38.46 \%$ or as many as 46 respondents chose the answer scale 4 (agree) and 5 (strongly agree), and in the item X1.10 
statement was $35.04 \%$ or as many as 41 respondents had an answer scale of 4 (agree) 5 (totally agree). This percentage is considered low when compared with the percentage of respondents who do not have an understanding of the capital market, which reaches $65 \%$. Although business owners do not understand capital market investment products, especially stocks, business owners understand that investing in capital market products has a higher risk level than investment risk in banking products. This understanding of the business owner can be obtained from information given to each other through community members at the start-up. Frequent sharing of information among community members will create community integration among community members. This is indicated in item X1.6 with the statement "In my opinion, stock investment is the safest type of investment from risk" and item X1.8 with the statement "When I diversify my investment, the risk of losing money increases". The percentage of the statement item X1.6 shows that as many as 81 respondents or $69.23 \%$ of respondents chose an answer scale of 1 (strongly disagree) to 3 (normal). While the percentage in item X1.8 shows $44.44 \%$ or as many as 52 respondents choose an answer scale of 1 (strongly disagree) to 3 (normal). This shows that the respondents do not understand the risk of investing in stocks, but rather understand investment risks. These results are also supported by the results of interviews which explain: "I don't know how to trade stocks. Usually, if I choose the type of stock that I want to buy, I will follow my friends in the community. But I know that investing in stocks is risky like the slogan "don't put eggs in one basket". (Informant 11, 2020)

The financial management dimension consists of 4 statement items, namely X1.12-X1.15. The results of the descriptive analysis of the dimensions of financial management show that financial management regarding credit guarantees has a high level of knowledge, but not short-term and long-term financial management. This is indicated in item X1.15 with the statement "When I use the house as collateral to apply for a loan, the possibility of me losing my house is very small or almost non-existent," which explains the credit guarantee. The percentage of respondent data shows that it is $52.14 \%$ or as many as 61 respondents choose an answer scale of 1 (strongly disagree) and 2 (disagree). This condition explains that the business owner understands very well that the high risk of a loan depends on the credit guarantee given and the size of the loan proposed. So that respondents in this category have a high level of knowledge about financial management, especially regarding credit guarantees. The results of the interview also shed light on this finding. "Of course, the amount of the loan also depends on the amount of collateral proposed. If you borrow up to hundreds of millions, it is impossible to guarantee only motorbikes certificate. There must be a risk of my guarantee being lost, I'm sure of that."(Informant 12, 2020).

However, these results are the opposite of the short-term and long-term financial management capabilities. Most business owners do not have a level of knowledge of shortterm and long-term financial management, this is shown in the percentage of item X1.13 and item X1.14. Item X1.13 has a questionnaire statement "The second main expense that I must fulfill is the preparation of pension funds", with a percentage of respondents of $42.74 \%$ or as many as 50 respondents having an answer scale of 4 (agree) and 5 (strongly agree). This percentage is said to be low when compared with the percentage of respondents who choose a scale of 1 (strongly disagree) to 3 (normal) of $57.26 \%$ or as many as 67 respondents. Similar conditions also occur in item X1.14 with the questionnaire statement "I should always provide liquid funds (such as cash/money in the bank) to meet my daily needs for about 2 - 6 months", with a percentage of respondents of $41.03 \%$ or as much as 48 respondents who chose the answer scale 4 (agree) and 5 (strongly agree). This is because most MSMEs only carry out simple financial records or management so that there is no special treatment (I forgot what is 
your Indonesian language) regarding long-term and short-term financial management. Even in some conditions, some SMEs do not record or manage finances. These MSMEs only focus on how many nominal sales are generated each day, so it is not surprising that most MSMEs do not know about financial management. The results of the interview also explained that "Yes, I made a financial report, but only a simple report. The report includes income and expenses per month. I also provide cash, but there is no detailed report. The cash is just a precaution if it runs out and I haven't provided cash anymore. While using personal money from my employees first, then I will replace it later. " (Informant 13, 2020)

"Me too. I just noted, how much was my profit today and how many pes of my products were sold. then how much will it be accumulated at the end of the month, how much is it left to deduct the expenses, that's looking for my profit. If I need sudden money, I will take it from the sales money. I'm confused, but right now that's all I can get." (Informant 14, 2020)

\subsection{Financial Experience}

The results of the financial experience analysis with the credit experience dimension show that most respondents have experience in short-term credit. This is shown in the descriptive processing of items X2.1, X2.2, X2.3, X2.5, X2.6, and X2.7. Items X2.1 through X2.3 describe statements regarding the experience of loans for education funds, practical loans, and home equity loans. The percentage shown by items X2.1 to X2.3 is that about $55 \%$ or about 65 respondents chose the answer scale of 4 (agree) and 5 (strongly agree). These results are also supported by descriptive data processing on items X2.5 to X.7. The percentage of respondents in item X2.5 with the statement item "I have taken a short-term loan (1 year or less)" indicates that $53.85 \%$ or 63 respondents chose an answer scale of 4 (agree) and 5 (agree). Item X2.6 with the statement "I get a loan in anticipation of a refund" also shows results that are not much different from item X2.5, as many as 63 respondents or $58.12 \%$ who choose an answer scale of 4 (agree) and 5 (strongly agree), and item X2.7 with the statement item "I get a loan offer" shows as many as 72 respondents or $61.54 \%$ of respondents choose an answer scale of 4 (agree) and 5 (strongly agree). Thus, the results of this data show that the business owner has experience in short-term loans, but not long-term credit experience as evidenced in item X2.4.

Item X2.4 with the statement item "I have taken a mortgage loan with collateral for immovable assets such as vehicle loans, home loans, machine and/or machine loans, equipment, and/or other fixed property purchase loans)", shows that $63.25 \%$ or as much as 74 respondents chose an answer scale of 1 (strongly disagree) to 3 (normal). This result is also supported by the results of item X2.8 with the item statement "I use a pawn shop" indicating that 72 respondents or $61.54 \%$ of respondents chose a scale of 1 (strongly disagree) to 3 (normal). Thus, most respondents have experience in short-term credit offered by banks, but no experience with non-bank financial institutions. This is in line with the knowledge possessed by business owners who are more familiar with banking than non-banking financial institutions. Business owners who feel more familiar with or know more about banking information than other non-bank financial institutions will prefer to make credit loans through banks. This is what forms the experience of business owners in making financing decisions. Ameliawati \& Setiyani (2018) said that financial experience is a person's learning behavior in managing personal finances so that someone who has adequate financial experience can behave more wisely in managing their finances than others. Financial experience as a factor related to financial management behavior is an event that occurs in individuals in response to several types of stimuli (Ameliawati \& Setiyani, 2018). Several previous studies have also 
stated that an individual's ability comes from experience (Fernandes \& Fich, 2011; Jiang et al., 2013), where experience is the main source of learning (Frijns et al., 2014). Besides, business owners or managers who have more experience will feel more familiar or more familiar with the environmental conditions of a company that is moving dynamically, so that the business owner or manager can respond responsively to existing problems. Supporting the previous statement, the research results of Jiang et al. (2013) also explained that CEOs with financial experience provide more precise income information and higher quality financial reports.

The results of the analysis on the dimensions of saving experience and capital market investment in the financial experience variable show that the business owner is not experienced in investing in capital market products, but has experience in banking products and capital market investment, which is described in items X2.9, X2.10, X2. 12, and X2.15. Items X2.9, X2.10, and X2.12 indicate that about $63 \%$ or about 63 respondents chose the answer scale 4 (agree) and 5 (strongly agree), which indicates that business owners are experienced in saving. The percentage on item X2.15 with the statement "I invest in Individual Shares", shows that $50.43 \%$ or as many as 59 respondents choose an answer scale of 4 (agree) and 5 (strongly agree). This condition explains that more than half of the research respondents have experience in saving and investing in the capital market. However, these results are slightly contrary to items X2.11, X2.13, and X2.14 as well as the analysis results from the aspect of financial knowledge.

The results of the analysis of items X2.11 and X2.13 which describe special banking products, namely current accounts and bonds, which show about $58.55 \%$ or as many as 68 respondents choose an answer scale of 1 (disagree) to 3 (normal). This result is also supported by item X2.14 which explains that $55.56 \%$ or as many as 65 respondents chose an answer scale of 1 (disagree) to 3 (normal), so it can be said that business owners or respondents are not experienced in special products from banking such as current accounts and bonds, as well as mutual fund investment products from the capital market. The results of this analysis also confirm the results of the analysis from the aspect of financial knowledge, which explains the indication of the herding behavior of the business owner. Herding behavior can be formed through strong bonds between members of the community that are followed so that when one member of the community invests and shows tantalizing results, other members are motivated to follow. This can be shown from the high number of business owners who have experience in stock investing but do not understand the risks of investing in stocks. The existence of this herding behavior was also clarified through the results of interviews from GGA regarding investment knowledge. Herding behavior has two effects, namely positive and negative. Herding behavior will bring a positive side when what is followed is equipped with knowledge and consideration. However, herding behavior will have a negative impact, if what is followed is only a prestigious event.

The results of the analysis on the financial management dimension for the financial experience variable show that business owners have no experience in financial management but have short-term financial management experience related to credit cards as a precautionary motive. The results of the analysis of X2.16, X2.17, X2.18, X2.21, X2.22, and X2.23 show that overall about $59 \%$ or about 46 respondents chose an answer scale of 1 (strongly disagree) to 3 ( normal), which shows 46 respondents have no experience in financial management. This is due to the lack of knowledge possessed by UMKM owners. The results of this analysis are not surprising, because the results of the analysis of financial knowledge variables also explain that business owners have a low level of knowledge about financial management both in the short term and in the perspective. The low level of financial knowledge that is owned will have an impact on the difficulties and skills 
shortages in managing company finances (Tuffour et al., 2020), and become one of the factors for the lack of motivation to be actively involved in personal and corporate financial planning (Loke, 2015). The results of the interview also confirm this opinion: "Although currently there are many financial literacy empowerment programs, they are still in the category of general matters, such as access to capital, basic matters of finance, marketing, and product quality standards. There is no further financial management yet." (Informant 16, 2020)

Apart from low knowledge, the length of time the business has been established and the level of gross income in one year also affect it. Most of the respondents have an income level of less than IDR $42,000,000$, so short-term financial management, especially credit cards, is not a top priority. This is indicated by item X2.19 with the statement item "I am charged late on the Credit Card bill" and X2.20 with the statement item "I make a payment that exceeds the credit limit". The percentage of item X2.19 is $63.25 \%$ or as many as 74 respondents choose an answer scale of 1 (disagree) to 3 (normal). The percentage of item X2.20 also shows results that are not much different, amounting to $64.01 \%$ or as many as 75 respondents choose an answer scale of 1 (disagree) to 3 (normal). The results of this analysis indicate that business owners are experienced in the use of credit cards, where the percentage contradicts the percentage of business owners who use credit cards, as shown in item X2.16. The function of credit cards, in this case, is for business needs, but only used for emergency needs or just a precaution, so it is not surprising that the percentage of credit card users with credit card experience is inversely related. "There is a credit card, but I rarely use it. I use it when I have to order products in large quantities, and have to pay cash. " (Informant 17, 2020)

\section{Conclusion}

This study found the fact that the financial knowledge of digital startups that are members of the Singo Edan Malang startup is at a moderate level. Basic knowledge regarding banking products and their mechanisms is better understood than investment products in the capital market. The matter of making financial decisions is still limited to considering the number of interest rates. Financial experience still encompasses short-term experience with a precautionary motive. Thus, the financial literacy of digital startups that are members of Startup Singo Edan Malang still has to be supported by many financial inclusion programs, but it doesn't stop there, the program will be more optimal if it carries community involvement so that the community can set certain standards for community members such as literacy levels. finances of each member of the community. The limitation of this study is that not all respondents understand financial terms so that in-depth interviews are needed in addition to distributing questionnaires. Input for further research is to consider the role of the community in the integration of creating financial knowledge and financial experiences.

\section{Acknowledgements}

The author would like to express his gratitude to all research respondents in "Startup Singo Edan Malang" Community. Besides, we do not forget to thank the Malang City Government.

\section{References}


[1] Ameliawati, M., \& Setiyani, R. (2018). The Influence of Financial Attitude, Financial Socialization, and Financial Experience to Financial Management Behavior with Financial Literacy as the Mediation Variable. KnE Social Sciences, 3(10), 811. https://doi.org/10.18502/kss.v3i10.3174

[2] Atkinson, A., \& Messy, F.-A. (2012). Measuring Financial Literacy: Results of the Oecd Infe Pilot Study. Oecd.

[3] Clark, G. L., Marshall, J. C., \& Strauss, K. (2009). Financial Knowledge. International Encyclopedia of Human Geography, 159-166. https://doi.org/10.1016/B978008044910-4.00161-9

[4] Du, M., Qiu, F., \& Xu, W. (2011). Construction of enterprises' financial knowledge management system (EFKMS). Procedia Environmental Sciences. https://doi.org/10.1016/j.proenv.2011.12.186

[5] Eniola, A., \& Ektebang, H. (2014). SME firms performance in Nigeria: Competitive advantage and its impact. International Journal of Research Studies in Management. https://doi.org/10.5861/ijrsm.2014.854

[6] Fernandes, N. G., \& Fich, E. M. (2011). Does Financial Experience Help Banks during Credit Crises? SSRN Electronic Journal, i. https://doi.org/10.2139/ssrn.1409557

[7] Frijns, B., Gilbert, A., \& Tourani-Rad, A. (2014). Learning by doing: The role of financial experience in financial literacy. Journal of Public Policy, 34(1), 123-154. https://doi.org/10.1017/S0143814X13000275

[8] Hantrakul, C., Thaloey, J., \& Songsangyos, P. (2012). The Review of Knowledge Management in Financial Industry. Procedia - Social and Behavioral Sciences, 69(Iceepsy), 2201-2204. https://doi.org/10.1016/j.sbspro.2012.12.186

[9] Hasting, J. S., Madrian, B. C., \& Skimmyhorn, W. L. (2012). Birational invariants, purity and the Gersten conjecture, in "K-theory and algebraic geometry: connections with quadratic forms and division algebras (Santa Barbara, CA, 1992)", 1-64. Nber Working Paper Series, 58, 1-42. https://doi.org/10.1146/annurev-economics-082312125807.NBER

[10] Huston, S. J. (2010). Measuring Financial Literacy. Journal of Consumer Affairs. https://doi.org/10.1111/j.1745-6606.2010.01170.x

[11] Jiang, F., Zhu, B., \& Huang, J. (2013). CEO's financial experience and earnings management. Journal of Multinational Financial Management, 23(3), 134-145. https://doi.org/10.1016/j.mulfin.2013.03.005

[12] Kachlami, H., \& Yazdanfar, D. (2016). Determinants of SME growth: The influence of financing pattern. An empirical study based on Swedish data. Management Research Review. https://doi.org/10.1108/MRR-04-2015-0093

[13] Kozlenkova, I. V., Samaha, S. A., \& Palmatier, R. W. (2014). Resource-based theory in marketing. In Journal of the Academy of Marketing Science. https://doi.org/10.1007/s11747-013-0336-7

[14] Lim, T. S., Mail, R., Abd Karim, M. R., Ahmad Baharul Ulum, Z. K., Jaidi, J., \& Noordin, R. (2018). A serial mediation model of financial knowledge on the intention to invest: The central role of risk perception and attitude. Journal of Behavioral and Experimental Finance, 20, 74-79. https://doi.org/10.1016/j.jbef.2018.08.001

[15] Loke, Y. J. (2015). Financial Knowledge and Behaviour of Working Adults in Malaysia. Margin, 9(1), 18-38. https://doi.org/10.1177/0973801014557392

[16] Lusardi, A., \& Tufano, P. (2015). Debt literacy, financial experiences, and overindebtedness. In Journal of Pension Economics and Finance (Vol. 14, Issue 4). https://doi.org/10.1017/S1474747215000232 
[17] Nonaka, I. (2002). A Dynamic Theory of Organizational Knowledge Creation. In C. W. Choo \& N. Bontis (Eds.), The Strategic Management of Intellectual Capital and Organizational Knowledge (1st ed., Vol. 24, Issue 5, pp. 437-462). Oxford University Press.

https://ejournal.poltektegal.ac.id/index.php/siklus/article/view/298\%0Ahttp://repositorio. unan.edu.ni/2986/1/5624.pdf\%0Ahttp://dx.doi.org/10.1016/j.jana.2015.10.005\%0Ahttp:/ /www.biomedcentral.com/1471-

2458/12/58\%0Ahttp://ovidsp.ovid.com/ovidweb.cgi?T=JS\&P

[18] Tang, N., \& Baker, A. (2016). Self-esteem, financial knowledge and financial behavior. Journal of Economic Psychology, 54, 164-176. https://doi.org/10.1016/j.joep.2016.04.005

[19] Tuffour, J. K., Amoako, A. A., \& Amartey, E. O. (2020). Assessing the Effect of Financial Literacy Among Managers on the Performance of Small-Scale Enterprises. Global Business Review. https://doi.org/10.1177/0972150919899753

[20] Ying, T., Jiang, J., \& Zhou, Y. (2015). Networks, citizenship behaviours and destination effectiveness: a comparative study of two Chinese rural tourism destinations. Journal of Sustainable Tourism. https://doi.org/10.1080/09669582.2015.1031672

[21] Yong, C. C., Yew, S. Y., \& Wee, C. K. (2018). Financial knowledge, attitude and behaviour of young working adults in Malaysia. Institutions and Economies, 10(4), 2148. 